\title{
Longitudinal variability in the zooplankton community of the upper Ob river
}

\author{
O.S. Burmistrova ${ }^{1}$, L.V. Yanygina ${ }^{1,2}$ \\ ${ }^{1}$ Institute for Water and Environmental Problems SB RAS, Molodezhnaya St., 1, Barnaul, Altai Krai \\ ${ }^{2}$ Altai State University, Lenin St. 61, 656049, Barnaul, Russian Federation \\ E-mail: burmolga@yandex.ru
}

Received: 14.08.2019. Accepted: 26.09.2019

\begin{abstract}
Zooplankton is important component of aquatic ecosystems playing the essential role in organic matter circulation and selfpurification of water bodies. Current data on zooplankton from one of the largest rivers in the world, i.e. the Ob river, is very fragmentary and cover small areas adjacent to large settlements. This paper presents the results of the zooplankton study of the 458-km stretch of the Ob river - from its source (Fominskoye village) up to the site above the Novosibirsk reservoir (Taradanovo village). To assess the longitudinal distribution of zooplankton, we collected samples from 17 river sections in different phases of a hydrological cycle, i.e. during the periods of flood (May-June) and summer low water (July-August) 2016. A total of 103 species and forms of zooplankton were detected. Rotifera dominated in species number.

In various river parts and hydrological cycle phases, species number, abundance and biomass of zooplankton differed significantly. Their maximum typically fell on the period of summer low water. Abundance and biomass of zooplankton tended to increase downstream. In most parts of the river, Rotifers was dominant in number, whereas copepods - in biomass (juvenile stages). Zooplankton distribution along the transversal profile of the river was characterized by the increased species number, abundance and biomass near the right bank (unlike the left one) that is, probably, due to the floodplain appearance on the right bank. An increase in zooplankton abundance was also observed in sites with a low flow velocity (river bays) and below the large tributaries. The assessment of water quality in the study site of the Ob river was performed based on the zooplankton composition and structure. A saprobic index for zooplankton is evidence of oligo- betamesosaprobic conditions.
\end{abstract}

Key words: Zooplankton, Longitudinal variability, Large rivers

\section{Introduction}

Studies of longitudinal distribution of organisms in rivers are a step forward in understanding the mechanisms of river ecosystems functioning. In spite of the growing interest to large rivers, our knowledge of their plankton is clearly insufficient (Napiórkowski \& Napiórkowska, 2013; Kim \& Joo, 2000). Of special interest is the identification of factors, which determine the distribution of planktonic organisms along the longitudinal and transversal profiles of large rivers.

Zooplankton organisms are identified as important components of aquatic ecosystems playing the essential role in transformation and circulation of organic matter, regulation of phytoplankton biomass and fish nutrition (especially at a larval stage) (Napiórkowski \& Napiórkowska, 2013; Dejen et al., 2004). The main factors limiting the development of riverine zooplankton are food availability, predator pressure, flow velocity, temperature and water quality (Kim \& Joo, 2000). Water residence time is of particular importance for plankton development in rivers (Basu \& Pick, 1996). The increase in river size brings to the increased water residence time that, in turn, results in downstream-directed increase in zooplankton abundance (Napiórkowski \& Napiórkowska, 2013). When a flow velocity grows, water residence time decreases, water turbidity and suspended sediment content in the water column increase. All this negatively affects zooplankton (Loginova \& Lopukh, 2011).

Noteworthy that the most complete data on the zooplankton composition and its structure are available for large European rivers (Napiórkowski \& Napiórkowska, 2013; Rossetti et al., 2009). Unfortunately, for Siberian rivers such data are fragmentary. The Ob is one of the largest rivers in the world; it springs from the confluence of the rivers Biya and Katun (the basins of which are located in the Altai Mountains) and flows into the Ob Bay of the Kara Sea. The river's length is $3680 \mathrm{~km}$, the catchment area - 2.9 million km $^{2}$ (Water of Russia..., 2000). A flow velocity in its upper sections during summer-autumn low water is $0.7-1.0 \mathrm{~m} / \mathrm{s}$, in the period of high water it increases up to $1.5-2.1 \mathrm{~m} / \mathrm{s}$ and at extreme floods it reaches $2.8 \mathrm{~m} / \mathrm{s}$ (Vasiliev et al., 2014).

The data on zooplankton from the upper stretches of the Ob are available for the mainstream near the city of Barnaul (Burmistrova, 2004; Kirillov et al., 1997; Romanova, 1963; Neizvestnova-Zhadina, 1929), some floodplain lakes (Vesnina, 2002) and ducts (Vesnina et al., 2015).

Our aim is to study the taxonomic composition and spatial distribution of zooplankton in the upper reaches of the Ob, i.e. in the site from its source to the Novosibirsk reservoir.

\section{Materials and Methods}

The object of our study was zooplankton collected from the 458-km section of the Ob - from its source (Fominskoye village) to the site above the Novosibirsk reservoir backwater (Taradanovo village). To assess the longitudinal distribution of zooplankton, samples were collected at 17 river sections in different phases of a hydrological cycle, i.e. during the periods of flood (May-June) and summer low water (July-August) 2016. Sampling was made in three points of 10 sites (right bank, mainstream, left bank); in other sites - only in the mainstream. For sampling, we used standard hydrobiological methods (Guidelines..., 1992). To collect zooplankton, we filtered 100 liters of water through the Apstein net (with a mesh size of $62 \times 62$ microns) in each sampling point. A 
total of 55 samples were analyzed. When identifying zooplankton species, we consulted "Rotifers in the USSR fauna (Rotatoria)" by L.A. Kutikova (1970) and "Key to Zooplankton and Zoobenthos from fresh waters of European Russia" (2010).

\section{Results and Discussion}

In the upper reaches of the Ob river, we identified 103 zooplankton species and forms (Table 1), among which Rotifera (79 species) predominated. The most common and abundant among Cladocera was Bosmina longirostris (Muller). In May-June, only 32 species and forms occurred in zooplankton. Rotifera dominated in species number (Table 1). Most zooplankton species were detected at river banks (right: 24 species, left: 26 species) maybe because of slowing-down of the flow in the coastal zone. The average number of species in a sample was low (3-5 species) almost throughout the river. The increase in zooplankton species number (up to 22 species in a sample) was typically observed in river sections below the mouth of a large tributary (i.e. Bolshaya Rechka river) and in the river bay (near the left bank of Chekanikha village, $97 \mathrm{~km}$ from the river head).

Table 1. Species number in different zooplankton groups from the upper reaches of the Ob in 2016.

\begin{tabular}{llccc}
\hline Sampling site & Groups & May-June & July-August & Total in 2016 \\
Left Bank & Rotifera & 23 & 38 & 49 \\
& Cladocera & 1 & 5 & 7 \\
Copepoda & 2 & 4 & 5 \\
Mainstream & Total & 26 & 47 & 61 \\
& Rotifera & 8 & 19 & 23 \\
& Cladocera & 0 & 8 & 8 \\
Right Bank & Copepoda & 4 & 5 & 7 \\
& Total & 12 & 32 & 38 \\
Rotifera & 20 & 60 & 66 \\
Cladocera & 1 & 10 & 10 \\
& Copepoda & 3 & 6 & 6 \\
& Total & 24 & 76 & 82 \\
& Rotifera & 27 & 73 & 79 \\
& Cladocera & 1 & 16 & 16 \\
& Copepoda & 4 & 8 & 8 \\
& Total & 32 & 97 & 103 \\
\hline
\end{tabular}

Overall, abundance (Fig.1) and biomass of zooplankton was basically low (20-310 ind. $\left./ \mathrm{m}^{3}, 0.03-1.50 \mathrm{mg} / \mathrm{m}^{3}\right)$. Only in some sites (river bays, channels or floodplain adjacent to the river), these indicators were significantly increased (up to 7500 ind./ $\mathrm{m}^{3}$ and 92.0 $\mathrm{mg} / \mathrm{m}^{3}$, respectively). Asplanchna priodonta Gosse and juvenile stages of Copepoda, including prevailing Rotifers of the genus Keratella, became the basis of zooplankton abundance and biomass (Figures 1 and 2).

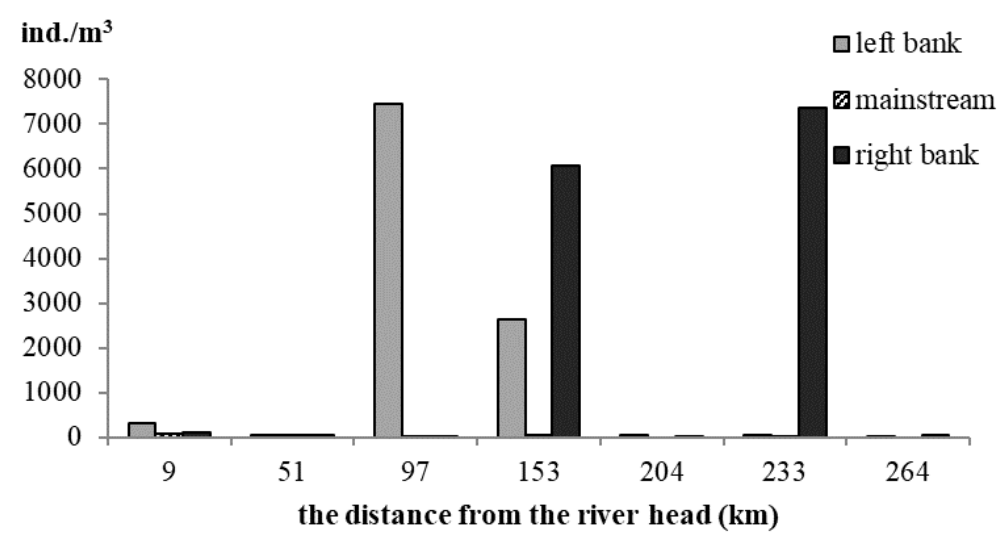

Figure 1. Zooplankton abundance in the upper reaches of the Ob river in May-June 2016.

In July-August, 97 species and forms of zooplankton were identified. Like in spring, Rotifera dominated in species number (Table 1). The largest number of species and forms of zooplankton (76 species) was detected near the right river bank that is, probably, due to zooplankton entered from the right-bank floodplain. The species number was much lower for the left bank (47 species) and minimal for the mainstream (32 species). As compared to the left bank (11 species), the average species number in a sample from the mainstream was low (approximately 5 species). The greatest richness of zooplankton was recorded near the right bank (on average 17 species). Downstream, this indicator increased from 2 species at Fominskoye village ( $9 \mathrm{~km}$ from the river head), up to 35 species at Kamyshenka village ( $233 \mathrm{~km}$ from the source). As in spring, the increase in zooplankton richness was marked in the mainstream below the site of the confluence of tributaries (Bolshaya Rechka, Kalmanka, Chumysh) and ducts (Bobrovskaya, Rechkunovskaya, Staritsa Obi, Staraya Ob) distinguished by a high content of organic substances. 
In summer, zooplankton abundance and biomass varied widely within $10-50000$ ind. $/ \mathrm{m}^{3}$ and $0.2-213.0 \mathrm{mg} / \mathrm{m}^{3}$, though in most sites they did not exceed 5000 ind. $/ \mathrm{m}^{3}$ and $50 \mathrm{mg} / \mathrm{m}^{3}$, respectively. As for the longitudinal profile, the minimum zooplankton abundance and biomass were recorded for $9 \mathrm{~km}$ below the confluence of the rivers Biya and Katun (near Fominskoye village). Zooplankton density tended to increase downstream in the mainstream up to the Novosibirsk reservoir (Fig.2). In the coastal zone, abundance and biomass of zooplankton varied greatly. At the left bank, their maximum was registered in the river bay near Chekanikha village ( $97 \mathrm{~km}$ from the source) that may be due to the intensive macrophyte development in this area. At the right bank, the maximum abundance was observed in the site above the Chumysh river mouth. Obviously, such an increased abundance occurred due to zooplankton drift from the floodplain. In the mainstream, mainly $A$. priodonta and Copepoda (juvenile stages) became the basis of abundance and biomass of riverine zooplankton.
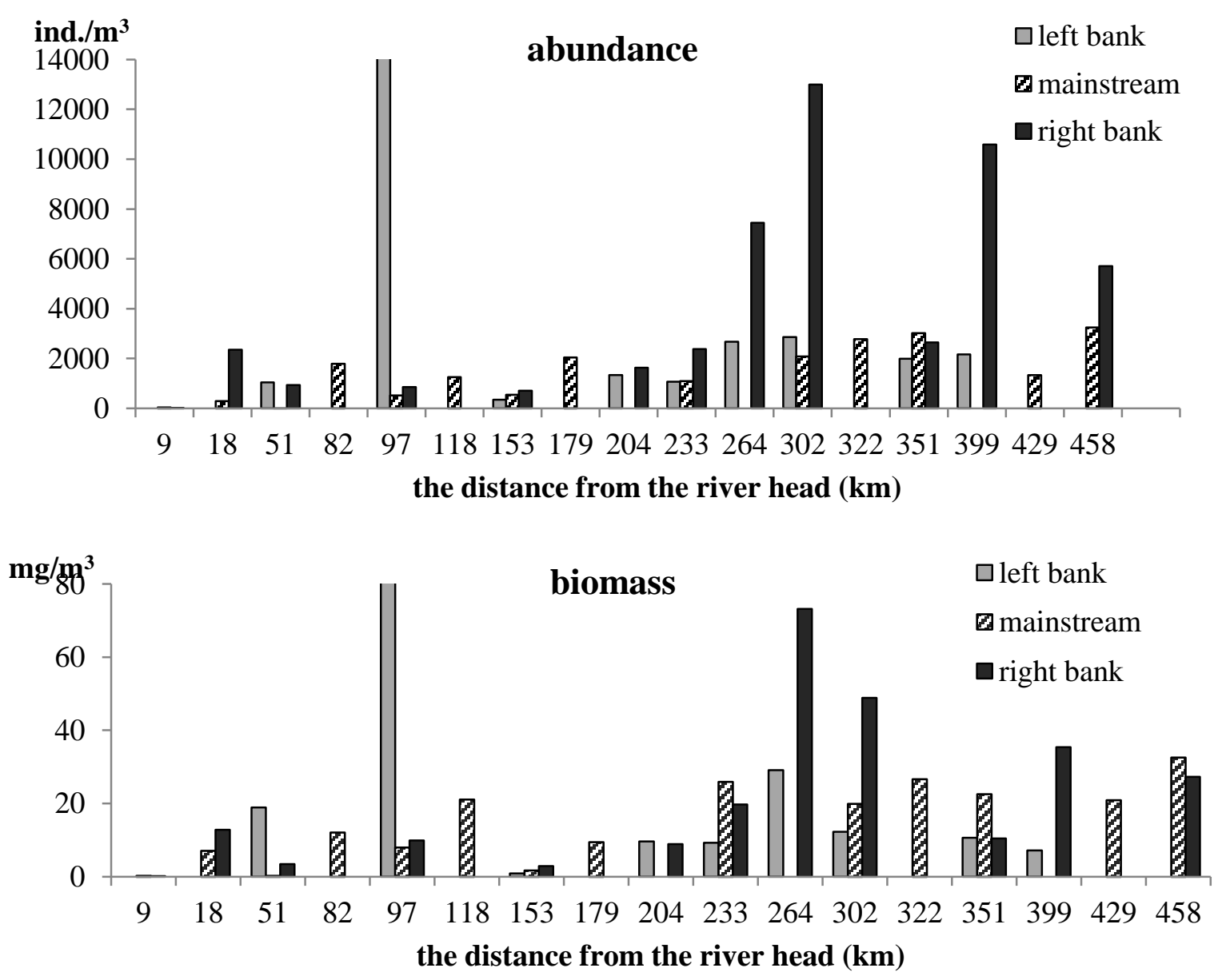

Figure 2. Abundance and biomass of zooplankton in the upper reaches of the Ob river in July-August 2016.

Saprobic index in spring and summer ( $1.37 \pm 0.21$ and $1.39 \pm 0.17$, respectively) generally indicate oligo- betamesosaprobic conditions of the studied area of the Ob river. By zooplankton structure, water is referred to class II (pure), except for some sites nearby villages Gonba and Kamyshenka with beta mesosaprobic conditions, quality class III, moderately polluted waters. The study showed that zooplankton of the Ob river was dominated by rotifers in species number (79 species). Such predominance of rotifers is characteristic of many rivers in Russia (Potemkina et al., 2016; Krylov, 2005; Sheveleva, 2004) and Europe (Dershe \& Skute, 2011; Friedrich \& Pohlmann 2009; Rossetti et al., 2009; Zimmermann-Timm et al., 2007; Mitrakhovich, 2003; Reckendorfer et al. 1999; Lair \& Reyes-Marchant, 1997; Parchuk \& Klochenko, 1997). It was suggested that rotifer dominance in rivers may be due to their smaller size and relatively short generation times compared to larger planktonic crustaceans (Lair, 2005). Over the period of our study, the largest species number, abundance and biomass of zooplankton were noted at the right bank (82 species) that is very likely associated with the right-bank floodplain appeared next to the river. It is known that the growth of planktonic invertebrates in transit is insufficient, and riverine zooplankton is supplemented by the organisms coming from the river-adjacent reservoirs with stagnant water (including river bays, ducts and floodplain habitats) acting as refugiums (Lair, 2006). Other studies prove the increase in species number, abundance and biomass of zooplankton not in the mainstream but in the coastal zone (Ball et al., 2018; Zimmermann-Timm et al., 2007).

\section{Conclusion}

In 2016, a total of 103 species and forms of zooplankton were detected in the upper reaches of the Ob river. Domination of Rotifera in species number was apparent. The maximum abundance and biomass of zooplankton typically fall on the period of summer low water. Zooplankton abundance and biomass show the downstream-directed increase in the mainstream of the river. In most river parts, Rotifers was dominant in species number, whereas copepods - in biomass (juvenile stages). The increase in zooplankton abundance was observed in the stretches with a low flow velocity (river bays) and below the large tributaries.

\section{Acknowledgements}

We wish to thank A.V. Kotovshchikov for assistance in sampling and L.A. Dolmatova for providing the hydrochemical data on the Ob river tributaries. The research was performed in the framework of the Federal Project (registration number AAAA-A17117041210244-5), whereas the field studies were supported by the Program for research fleet-based investigations of the RF Ministry of Education and Science. 


\section{References}

Ball, E.E., Smith, D.E., Anderson, E.J., Skufca, J.D. \& Twiss, M.R. (2018). Water velocity modeling can delineate nearshore and main channel plankton environments in a large river. Hydrobiologia, 815, 125-140. doi: 10.1007/s10750-018-3556-5

Basu, K.B. \& Pick, F.R. (1996). Factors regulating phytoplankton and zooplankton biomass in temperate rivers. Limnol. Oceanogr., $41(7), 1572-1577$.

Burmistrova, O.S. (2004.) Zooplankton in the Ob river (near the city of Barnaul) in 2001-2002. Siberian Zoological Conference: Proceed. of Russ. conf. devoted to the 60th anniversary ISEA SB RAS (Novosibirsk, 15-22 September 2004), 24-25. (In Russian) Dejen, E., Vijverberg, J., Nagelkerke, L.A.J. \& Sibbing, F.A. (2004). Temporal and spatial distribution of microcrustacean zooplankton in relation to turbidity and other environmental factors in a large tropical lake (L.Tana, Ethiopia). Hydrobiologia, 513, 39-49.

Dershe, R. \& Skute, A. (2011). The influence of ecohydrological factors on the cenosis of the Daugava River zooplankton. Acta Zoologica Lituanica, 21 (2), 133-144. doi: 10.2478/v10043-011-0013-3

Friedrich, G. \& Pohlmann, M. (2009). Long-term plankton studies at the lower Rhine (Germany). Limnologica, 39, 14-39. doi: 10.1016/j.limno.2008.03.006

Guidelines for hydrobiological monitoring of freshwater ecosystems. (1992). Saint Petersburg, Gidrometeoizdat. (In Russian)

Key to zooplankton and zoobenthos of fresh waters of European Russia. V.1. Zooplankton. (2010). Moscow, Association of scientific publications. (In Russian)

Kim, H.W. \& Joo, G.J. (2000). The longitudinal distribution and community dynamics of zooplankton in a regulated large river: a case study of the Nakdong River (Korea). Hydrobiologia, 438, 171-184.

Kirillov, V.V., Kiknadze, I.I., Rudneva, L.V., Vesnina, L.V., Egorkina, G.I., Mitrofanova, E.Yu., Zarubina, E.Yu., Kim, G.V., Kirillova, T.V. \& Matveeva, O.V. (1997). Biological diversity of aquatic ecosystems in the Upper Ob basin. Ob Vestnik, 2-3, 61-67. (In Russian)

Krylov, A.V. (2005) Zooplankton of lowland small rivers. Moscow, Nauka. (In Russian)

Kutikova, L.A. (1970). Rotifers in the USSR fauna (Rotatoria). Leningrad, Nauka. (In Russian)

Lair, N. \& Reyes-Marchant, P. (1997). The potamoplankton of the Middle Loire and the role of the'moving littoral' in downstream transfer of algae and rotifers. Hydrobiologia, 356, 33-52.

Lair, N. (2005). Abiotic vs. biotic factors: Lessons drawn from rotifers in the Middle Loire, a meandering river monitored from 1995 to 2002 , during low flow periods. Hydrobiologia, 546, 457-472.

Lair, N. (2006). A review of regulation mechanisms of metazoan plankton in riverine ecosystems: aquatic habitat versus biota. River Research and Applications, 22, 567-593.

Loginova, E.V. \& Lopukh, P.S. (2011). Hydroecology: a course of lectures. Minsk, BSU. (In Russian)

Mitrakhovich, P.A. (2003). Zooplankton of the Svisloch river and its seasonal dynamics nearby Minsk. Lake ecosystems: biological processes, anthropogenic transformation, water quality: Proceed. of II intern. sci. conf. (22-26 September 2003, Minsk-Naroch). Minsk, BSU, 484-487. (In Russian)

Napiórkowski, P., \& Napiórkowska, T. (2013). The diversity and longitudinal changes of zooplankton in the lower course of a large, regulated European river (the lower Vistula River, Poland). Biologia, 68(6), 1163-1171. doi:10.2478/s11756-013-0263-6

Neizvestnova-Zhadina, E.S. (1929) Studying the microfauna of the Ob river and its basin. Bulletin of SHI, 25, 59-70. (In Russian)

Parchuk, G.V. \& Klochenko, P.D. (1997). Comparative characteristics of zooplankton from Dnieper tributaries. Hydrobiological journal, 33 (3), 14-28. (In Russian)

Potemkina, T.V., Sheveleva, N.G., Shaburova, N.I., Misharina, E.A. \& Knizhin, I.B. (2016). Structure and Quantitative Characteristics of Zooplankton and Zoobenthos in the upper reaches of Lena and water bodies. Journal of Siberian Federal University. Biology, 3 , 313-329 (In Russian)

Reckendorfer, W., Keckeis, H., Winkler, G \& Schiemer, F. (1999). Zooplankton abundance in the River Danube, Austria: The significance of inshore retention. Freshwater Biology, 41, 583-591.

Romanova, G.P. (1963). To the study of zooplankton and zoobenthos of the upper reaches of the Ob river. Nature of the Ob river floodplain and its economic development. Tomsk University, 152, 115-125. (In Russian)

Rossetti, G., Viaroli, P. \& Ferrari, I. (2009). Role of abiotic factors in structuring the metazoan plankton community in a lowland river. River Research and Applications, 25(7), 814-835.

Sheveleva, N.G. (2004). Features of zooplankton diversity in large Siberian rivers (Yenisei, Selenga, Lena). In: Proceed. of Russ. conf. devoted to the 60th anniversary ISEA SB RAS, September 15-22. Novosibirsk, 90. (In Russian)

Vasiliev, O.F., Zinoviev, A.T., Koshelev, K.B., Dyachenko, A.V. \& Kolomeytsev, A.A. (2014). Extreme rain flood of 2014 in the Upper Ob basin: its formation, forecasting and field observations. Water and environmental problems of Siberia and Central Asia: Proceed. of Russ. Sci. Conf. with intern. participation. Barnaul, IWEP SB RAS, 1, 9-16. (In Russian)

Vesnina, L.V. (2002). Zooplankton in lake ecosystems of the Altai Krai plain. Novosibirsk, Nauka. (In Russian)

Vesnina, L.V., Surkov, D.A., Piatkova, Ia.S., Kuznetsova, K.A. \& Ershov, N.N. (2015). Zooplankton and zoobenthos in water bodies of polytypic landscape zones of Altai Krai. Bulletin of fisheries science, 2(4), 71-85. (In Russian)

Water of Russia. River basins. (2000). Ekaterinburg, AQUA-Press. (In Russian)

Zimmermann-Timm, H., Holst, H. \& Kausch, H. (2007). Spatial dynamics of rotifers in a large lowland river, the Elbe, Germany: How important are retentive shoreline habitats for plankton community? Hydrobiologia, 593, 49-58. doi: 10.1007/s10750-007-9046-9

\section{Citation:}

O.S. Burmistrova, L.V. Yanygina (2019). Longitudinal variability in the zooplankton community of the upper Ob river. Ukrainian Journal of Ecology, g(3), 367-370.

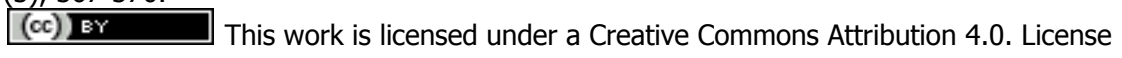

